\title{
Efficacy of targeted agents in the treatment of elderly patients with advanced non-small-cell lung cancer: a systematic review and meta-analysis
}

This article was published in the following Dove Press journal:

OncoTargets and Therapy

2 August 2016

Number of times this article has been viewed

\section{Jianqing Chen \\ Jianbo Chen \\ Xiaoan Wu \\ Tao Shi \\ Meiling Kang}

Department of Medical Oncology, The Affiliated Chenggong Hospital, Xiamen University, Xiamen, Fujian Province, People's Republic of China
Correspondence: Jianqing Chen Department of Medical Oncology, The Affiliated Chenggong Hospital, Xiamen University, No 92-96, Wenyuan Road, Siming Area, Xiamen 361003, Fujian Province, People's Republic of China Tel +865922136660 Email chenjianqing2015@sina.com
Purpose: The efficacy of targeted agents (TAs) in the treatment of elderly patients with advanced non-small-cell lung cancer (NSCLC) remains controversial. We aimed to assess the efficacy of TAs in the treatment of advanced NSCLC in this setting.

Materials and methods: Relevant trials were identified by searching electronic databases and conference meetings. Prospective randomized controlled trials assessing chemotherapies with or without TAs in elderly patients with advanced NSCLC were included. Outcomes of interest included overall survival (OS) and progression-free survival (PFS) in elderly patients with advanced NSCLC.

Results: A total of 4,093 elderly patients from 17 randomized controlled trials were included for analysis. The addition of TAs to chemotherapy significantly improved PFS (hazard ratio [HR] $0.85,95 \%$ confidence interval $[\mathrm{CI}]: 0.75-0.96, P=0.01)$ when compared to chemotherapy alone. There was also a tendency to improve OS in the combination groups (HR 0.92, 95\% CI: 0.85-1.01, $P=0.064)$. Subgroup analysis based on treatment line indicated that TAs plus chemotherapy as first-line chemotherapy in elderly patients with advanced NSCLC significantly improved PFS (HR $0.80,95 \%$ CI: $0.68-0.95, P=0.01$ ) and OS (HR 0.91, 95\% CI: $0.83-0.99, P=0.037$ ), while the use of TA-containing regimens as second-line therapy in these patients did not significantly improve PFS (HR 0.91, 95\% CI: $0.75-1.10, P=0.33$ ) and OS (HR 1.04, 95\% CI: $0.81-1.33, P=0.77$ ) in comparison with chemotherapy alone. No publication bias was detected by Begg's and Egger's tests for OS. Conclusion: The findings of this study suggest that the addition of TAs to first-line chemotherapy in elderly patients with advanced NSCLC offers an improved PFS and OS. Further trials are recommended to clearly investigate the efficacy of adding specific TAs to first-line chemotherapy for advanced NSCLC in this setting.

Keywords: non-small-cell lung cancer, elderly, targeted agents, randomized controlled trials, meta-analysis

\section{Introduction}

Lung cancer is the leading cause of cancer-related mortality worldwide, accounting for almost 1.4 million deaths each year. ${ }^{1}$ Approximately $85 \%$ of these patients have non-small-cell lung cancer (NSCLC) and more than two-thirds are older than 65 years. $^{2}$ Demographics that are shifting toward an older population suggest that oncologists will be seeing more elderly patients with lung cancer in years to come.,4 However, there are many challenges involved in the treatment of an elderly population with advanced NSCLC. Many of these patients have more comorbidities and tend to be less tolerant to toxic medical treatments than their younger counterparts. ${ }^{5}$ Moreover, only $35 \%$ of patients with regional disease and $27 \%$ with metastatic 
disease received guideline-recommended treatment among patients aged $\geq 65$ years. ${ }^{6}$ Therefore, the optimal treatment for NSCLC in elderly patients remains unknown.

In current practice, there is a significant underrepresentation of elderly patients in most clinical trials on lung cancer. ${ }^{7-9}$ However, previous clinical trials have shown that systematic chemotherapy would benefit elderly patients if they were carefully selected. ${ }^{10,11}$ Subsequently, two meta-analyses also demonstrated that doublet combination chemotherapy was superior to a single third-generation cytotoxic agent for the treatment of elderly patients with advanced NSCLC. ${ }^{12,13}$ Although these data have provided the rationale to treat fit elderly patients with standard chemotherapy regimens, a large number of elderly patients are still undertreated.

In recent decades, the emergence of molecularly targeted agents (TAs) has provided a novel treatment option for elderly patients with advanced NSCLC. ${ }^{8,14-16}$ Several drugs designed to interfere with specific aberrant biological pathways in NSCLC, including angiogenesis inhibitors targeting vascular endothelial growth factors (VEGFs) pathway (anti-VEGF monoclonal antibody including bevacizumab ${ }^{17}$ and ramucirumab ${ }^{18}$ ) and epidermal growth factor receptor (EGFR) tyrosine kinase inhibitors (including erlotinib ${ }^{19}$ and gefitinib $\left.{ }^{20,21}\right)$, have been approved for use in advanced NSCLC due to their potential survival benefits. In addition, other TAs are at varying stages of clinical development, such as anti-EGFR monoclonal antibodies (cetuximab and necitumumab), immune modulator (thalidomide), and small multikinase inhibitor targeting VEGF receptor/plateletderived growth factor receptor/FLT-3/c-KIT (sorafenib, motesanib, nintedanib, and vandetanib). Although the trials that established the efficacy of these agents allow the enrollment of patients older than 70 years, the elderly patients constitute the minority. Additionally, the elderly patients in these clinical trials are not entirely representative of the overall elderly patient population due to the stringent enrollment criteria on organ function and performance status. As a result, the applicability of the data of these trials to the overall patient population needs to be cautious due to the lack of trials dedicated specifically to the elderly population. Thus, we perform this meta-analysis of all available randomized controlled trials (RCTs) to determine the overall efficacy of TAs in NSCLC patients aged $\geq 65$ years.

\section{Materials and methods Selection of studies}

The PubMed, Embase, and Cochrane Library electronic databases were search to identify relevant studies of TAs in advanced NSCLC (published before September 31, 2015). The search was limited to human studies and RCTs. No language restriction was imposed. The keywords are "bevacizumab", “avastin”, “aflibercept”, "VEGFRTKIs", “sorafenib", "nexavar", “sunitinib”, "sutent”, "SU1248”, "vandetanib”, “caprelsa”, "ZD6474”, “axitinib", "pazopanib”, "votrient”, “GW786034”, "regorafenib", "apatinib", "ramucirumab", "nintedanib", "BIBF1120", "thalidomide", "lenalidomide", "angiogenesis inhibitors", “cetuximab”, "panitumumab”, "erlotinib”, "gefitinib", "afatinib", "randomized", and "non-small-cell lung cancer". In addition, we searched abstracts and virtual meeting presentations from the American Society of Clinical Oncology (http://www.asco.org/ASCO) conferences for relevant trials (from January 2004 to June 2015). If duplicate data were presented in several studies, only the most informative or complete articles were included.

\section{Data extraction and clinical end point}

Two authors independently extracted the following data according to the Preferred Reporting Items for Systematic Reviews and Meta-Analysis (PRISMA) statement, ${ }^{22}$ and any discrepancy between the reviewers was resolved by consensus. The following data were extracted: first author, year of publication, trial phase, number of elderly patients, treatment arms, age, primary end points, and median follow-up. A standardized Excel file was used for data extraction. Trials that met the following inclusion criteria were included: 1) study design, RCT; 2) population, patients were pathologically confirmed of NSCLC; 3) intervention, comparing chemotherapies with or without TAs; and 4) outcome measure, the study had sufficient survival data of elderly patients ( $\geq 65$ years) for extraction. We used the Jadad score to assess the quality of clinical trials, which was calculated by using the five-item Jadad scale, including randomization, double-blinding, and withdrawals, as described previously. ${ }^{23}$

\section{Data analysis}

We assessed the overall efficacy of adding TAs to therapies in the treatment of elderly patients with advanced NSCLC. The outcomes used were 1) overall survival (OS), defined as the time from random assignment to death from any cause, censoring patients who had not died at the date last known alive and 2) progression-free survival (PFS), defined as the time from random assignment to first documented progression. PFS and OS were treated as time-to-event variables and thus were expressed as hazard ratios (HRs) with 95\% confidence intervals [CI] for each study. Between-study heterogeneity was estimated 
using the chi-square $\left(\chi^{2}\right)$-based $Q$ statistic. ${ }^{24}$ The $I^{2}$ statistic was also calculated to evaluate the extent of variability attributable to statistical heterogeneity between trials. $I^{2}$ values of $25 \%, \sim 50 \%$, $\sim 75 \%$, and $\sim 100 \%$ indicated no, low, moderate, and high heterogeneities, respectively. We pooled the analysis according to the heterogeneity among the included trials. To investigate the sources of heterogeneity, we also conducted predefined subgroup analysis according to treatment line. Additionally, we used the Begg's and Egger's tests to assess the publication bias. ${ }^{25}$

\section{Results}

\section{Search results}

The initial search of the PubMed, Embase, and Cochrane Library electronic databases yielded a total of 450 potentially relevant studies. Of these, 433 were excluded for the reasons shown in Figure 1. Sixteen published RCTs with subgroup analysis assessing the efficacy of TAs in elderly patients were included in the meta-analysis. One additional RCT investigating the efficacy of vandetanib in elderly patients with NSCLC was included. ${ }^{26}$ Finally, a total of 17 trials were included for analysis. The main characteristics of each trial are presented in Table 1. A total of 4,093 patients were available. Fourteen trials were performed in first-line settings, ${ }^{17,18,26-37}$ and three in second-line settings. ${ }^{38-40}$ Thirteen trials were randomized Phase III trials, , ${ }^{17,-36,38,39-40}$ and three were randomized Phase II trials. ${ }^{18,26,37}$ The quality of each included study was roughly assessed according to Jadad scale, and six trials had Jadad score of 5, and eleven trials had Jadad score of 3.

\section{Overall survival}

Eleven trials with 13 comparisons reported OS data of elderly patients. The pooled results demonstrated that the

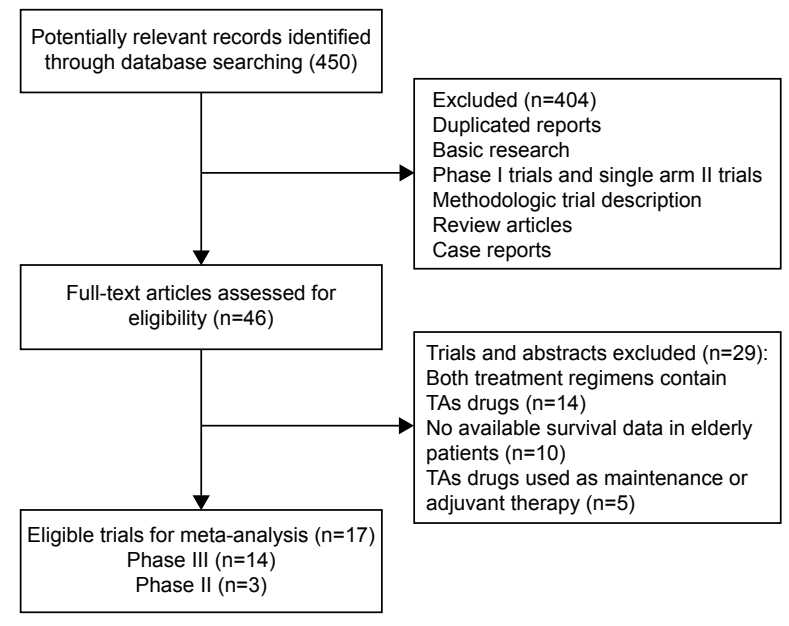

Figure I Studies eligible for inclusion in the meta-analysis. Abbreviation: TA, targeted agent. addition of TAs to chemotherapy had a tendency to improve OS in comparison with chemotherapy alone (HR 0.92, 95\% CI: 0.85-1.01, $P=0.064$, Figure 2) using a fixed-effects model. We then performed subgroup analysis according to treatment line and found that trials using TA-containing regimens as first-line therapy (HR 0.91, 95\% CI: 0.83-0.99, $P=0.037$ ) significantly improved OS when comparing chemotherapy alone but not for second-line therapies (HR 1.04, 95\% CI: $0.81-1.33, P=0.77)$. We then performed subgroup analysis according to specific TAs and found that the use of anti-EGFR agents significantly improved OS (HR 0.87, 95\% CI: $0.77-0.98, P=0.024)$ but not for anti-VEGF agents (HR 0.97, 95\% CI: 0.86-1.10, $P=0.65$ ).

\section{Progression-free survival}

Ten trials with 12 comparisons reported PFS data. The pooled HR for PFS demonstrated that the addition of TAs to chemotherapies significantly improved PFS giving HR 0.85 (95\% CI: $0.75-0.96, P=0.01$, Figure 3), compared with chemotherapy alone. There was significant heterogeneity between trials $\left(I^{2}=47.3 \%, P=0.035\right)$, and the pooled HR for PFS was performed by using random-effects model. We performed subgroup analysis according to treatment line and found that the addition of TAs to chemotherapy significantly improved PFS as first-line therapy (HR 0.80, 95\% CI: $0.68-0.95, P=0.01)$ in elderly patients with advanced NSCLC but not for second-line therapy (HR 0.91, 95\% CI: 0.75-1.10, $P=0.33$ ). Additionally, we performed subgroup analysis according to specific TAs and found that the use of anti-VEGF agents significantly improved PFS (HR 0.81, 95\% CI: $0.69-0.96, P=0.012)$ and a marginally significant PFS benefits for anti-EGFR agents (HR 0.89, 95\% CI: $0.79-1.01, P=0.06)$.

\section{Publication bias}

We performed Begg's funnel plot and Egger's test to assess the publication bias of literatures. The Begg's funnel plots revealed no evidence of publication bias $(P=0.63$ for $\mathrm{OS}$ and $P=0.15$ for PFS). Additionally, Egger's test still did not suggest any evidence of publication bias for OS $(P=0.83)$ but it did detect potential publication bias for PFS $(P=0.003)$. The differences in the results obtained from the two methods might be due to a greater statistical power of the regression methods. ${ }^{41}$

\section{Discussion}

During the past few decades, the introduction of biological agents targeting specific signal pathways related to tumor growth and survival, including EGFR and the VEGF signaling 
Table I Baseline characteristic of included 17 trials for analysis

\begin{tabular}{|c|c|c|c|c|c|c|c|c|}
\hline Author/year & Phase & $\begin{array}{l}\text { Line of } \\
\text { treatment }\end{array}$ & $\begin{array}{l}\text { No of elderly } \\
\text { patients }\end{array}$ & Age & Targets & Treatment regimens & $\begin{array}{l}\text { Primary } \\
\text { end point }\end{array}$ & $\begin{array}{l}\text { Jadad } \\
\text { score }\end{array}$ \\
\hline $\begin{array}{l}\text { Zhou et a }\left.\right|^{32} \\
(2015)\end{array}$ & III & First line & 53 & $\geq 65$ & VEGF & $\begin{array}{l}\text { Bev }+ \text { PTX }+ \text { CBP } \\
\text { Placebo }+ \text { PTX }+ \text { CBP }\end{array}$ & PFS & 5 \\
\hline $\begin{array}{l}\text { Doebele et al }{ }^{18} \\
(2015)\end{array}$ & II & First line & 66 & $\geq 65$ & VEGFR-2 & $\begin{array}{l}\text { Ramucirumab }+ \text { pemetrexed }+ \\
\text { platinum } \\
\text { Pemetrexed + platinum }\end{array}$ & PFS & 3 \\
\hline $\begin{array}{l}\text { Thatcher et a }{ }^{35} \\
(20 I 5)\end{array}$ & III & First line & 421 & $\geq 65$ & EGFR & $\begin{array}{l}\text { Necitumumab + Gem + DDP } \\
\text { Gem + DDP }\end{array}$ & OS & 3 \\
\hline $\begin{array}{l}\text { Soria et a } 4^{40} \\
(2015)\end{array}$ & III & Second line & 77 & $\geq 65$ & EGFR & $\begin{array}{l}\text { Gefitinib + pemetrexed + DDP } \\
\text { Pemetrexed + DDP }\end{array}$ & PFS & 3 \\
\hline $\begin{array}{l}\text { Paz-Ares et al }{ }^{34} \\
(20 \mid 5)\end{array}$ & III & First line & 115 & $\geq 65$ & EGFR & $\begin{array}{l}\text { Necitumumab + pemetrexed + DDP } \\
\text { Pemetrexed + DDP }\end{array}$ & OS & 3 \\
\hline $\begin{array}{l}\text { Garon et al }{ }^{39} \\
(2014)\end{array}$ & III & Second line & 252 & $\geq 70$ & VEGFR-2 & $\begin{array}{l}\text { Ramucirumab + Doc } \\
\text { Placebo + Doc }\end{array}$ & OS & 5 \\
\hline $\begin{array}{l}\text { Reck et al }{ }^{38} \\
(20 \mid 4)\end{array}$ & III & Second line & 158 & $\geq 65$ & $\begin{array}{l}\text { VEGFR-I, -2, -3; PDGFR; } \\
\text { FGFR-I, -2, -3; Flt-3 }\end{array}$ & $\begin{array}{l}\text { Nintedanib + Doc } \\
\text { Placebo + Doc }\end{array}$ & PFS & 5 \\
\hline $\begin{array}{l}\text { Gridelli et } \mathrm{al}^{26} \\
(2014)\end{array}$ & II & First line & 124 & $\geq 70$ & VEGFR-2, -3; EGFR & $\begin{array}{l}\text { Vandetanib }+ \text { Gem } \\
\text { Placebo }+ \text { Gem }\end{array}$ & PFS & 5 \\
\hline $\begin{array}{l}\text { Wu et } a^{36} \\
(2013)\end{array}$ & III & First line & 102 & $\geq 65$ & EGFR & $\begin{array}{l}\text { Erlotinib }+ \text { Gem }+ \text { platinum } \\
\text { Gem + platinum }\end{array}$ & PFS & 3 \\
\hline $\begin{array}{l}\text { Scagliotti et al }{ }^{31} \\
(20 \mid 2)\end{array}$ & III & First line & 370 & $\geq 65$ & $\begin{array}{l}\text { VEGFR-I, -2, -3; PDGFR; } \\
\text { Flt-3; c-kid }\end{array}$ & $\begin{array}{l}\text { Motesanib }+ \text { PTX }+ \text { CBP } \\
\text { Placebo }+ \text { PTX }+ \text { CBP }\end{array}$ & OS & 5 \\
\hline $\begin{array}{l}\text { Hoang et } \mathrm{al}^{27} \\
(2012)\end{array}$ & III & First line & 546 & $\geq 65$ & Antiangiogenic agents & $\begin{array}{l}\text { Thalidomide + PTX + CBP + RT } \\
\text { PTX + CBP + RT }\end{array}$ & OS & 3 \\
\hline $\begin{array}{l}\text { Niho et } \mathrm{al}^{37} \\
(2012)\end{array}$ & II & First line & 67 & $\geq 65$ & VEGF & $\begin{array}{l}\text { Bevacizumab }+ \text { PTX }+ \text { CBP } \\
\text { PTX }+ \text { CBP }\end{array}$ & PFS & 3 \\
\hline $\begin{array}{l}\text { Scagliotti et al }{ }^{30} \\
(2010)\end{array}$ & III & First line & 381 & $\geq 65$ & $\begin{array}{l}\text { b-Raf, VEGFR-2, -3; } \\
\text { PDGFR; FIt-3; c-kid }\end{array}$ & $\begin{array}{l}\text { Sorafenib }+\mathrm{CBP}+\mathrm{PTX} \\
\mathrm{CBP}+\mathrm{PTX}\end{array}$ & OS & 3 \\
\hline $\begin{array}{l}\text { Lynch et } \mathrm{a}^{28} \\
(2010)\end{array}$ & III & First line & 340 & $\geq 65$ & EGFR & $\begin{array}{l}\text { Cetuximab }+ \text { taxane }+ \text { CBP } \\
\text { Taxane }+ \text { CBP }\end{array}$ & PFS & 3 \\
\hline $\begin{array}{l}\text { Reck et } \mathrm{al}^{29} \\
(2009)\end{array}$ & III & First line & 304 & $\geq 65$ & VEGF & $\begin{array}{l}\text { Bev } 7.5 \mathrm{mg} / \mathrm{kg}+\mathrm{DDP}+\mathrm{Gem} \\
\text { Bev } 15 \mathrm{mg} / \mathrm{kg}+\mathrm{DDP}+\mathrm{Gem} \\
\text { Placebo + DDP + Gem }\end{array}$ & PFS & 5 \\
\hline $\begin{array}{l}\text { Pirker et al }{ }^{33} \\
(2009)\end{array}$ & III & First line & 351 & $\geq 65$ & EGFR & $\begin{array}{l}\text { Cetuximab + vinorelbine + DDP } \\
\text { Vinorelbine + DDP }\end{array}$ & OS & 3 \\
\hline $\begin{array}{l}\text { Sandler et al }{ }^{17} \\
(2006)\end{array}$ & III & First line & 366 & $\geq 65$ & VEGF & $\begin{array}{l}\text { Bev } 15 \mathrm{mg} / \mathrm{kg}+\mathrm{CBP}+\mathrm{PTX} \\
\mathrm{CBP}+\mathrm{PTX}\end{array}$ & OS & 3 \\
\hline
\end{tabular}

Abbreviations: VEGF, vascular endothelial growth factor; Bev, bevacizumab; PTX, paclitaxel; CBP, carboplatin; PFS, progression-free survival; VEGFR, vascular endothelial growth factor receptor; EGFR, epidermal growth factor receptor; Gem, gemcitabine; DDP, cisplatin; OS, overall survival; Doc, docetaxel; RT, radiotherapy.

cascade, represents the most promising option to improve survival outcome for patients with advanced NSCLC. ${ }^{42,43}$ However, there are limited data specifically focusing on the efficacy of TAs in elderly patients with advanced NSCLC. We therefore conducted this meta-analysis of RCTs with preplanned and unplanned subset analysis of elderly patients ( $\geq 65$ years) to investigate the overall efficacy of TAs in the treatment of advanced NSCLC in this setting.

To our best knowledge, this is the first meta-analysis to assess the efficacy of adding TAs to chemotherapy in elderly patients with advanced NSCLC. Our study, including 4,026 patients from 17 RCTs, demonstrates that the addition of TAs to chemotherapy in elderly patients with advanced NSCLC significantly improves PFS, and there is also a tendency to improve OS in the combination groups. Subgroup analysis according to treatment line shows that the addition of TAs to first-line chemotherapy significantly improves PFS and OS, while no significant survival benefits have been observed in TAs plus second-line chemotherapy. Based on our results, we could conclude that the combination of TAs plus chemotherapy could be recommended as first-line treatment for elderly patients with advanced NSCLC, but 


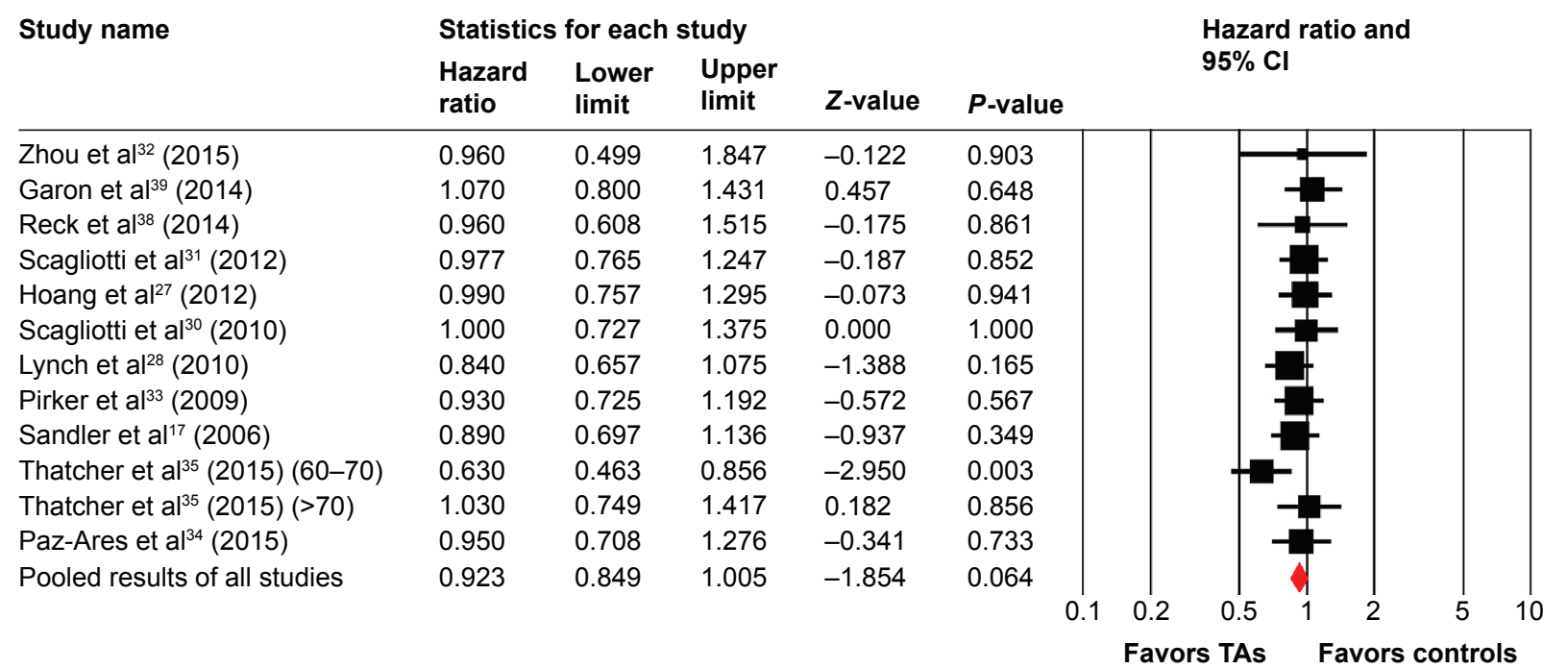

Figure 2 Fixed-effects model of hazard ratio $(95 \% \mathrm{Cl})$ of OS associated with chemotherapy with or without TAs.

Notes: Thatcher et al, ${ }^{35}$ divided older patients into two groups $(60-70$ and $>70)$ within their study, as both groups consist of patients with NSCLC treated with targeted agents. Thus, the efficacy of targeted agents in these two groups are different so they are displayed separately.

Abbreviations: $\mathrm{Cl}$, confidence interval; OS, overall survival; TA, targeted agent.

more evidence is still required to identify patients who will most likely benefit for the specific TAs plus chemotherapy. Due to only three RCTs assessing the efficacy of TAs plus second-line chemotherapy in elderly patients for analysis, we acknowledge that data are immature to make an exact conclusion about the role of TAs in this setting, and more evidence is still needed to clearly set the role of adding TAs to second-line chemotherapy for elderly patients with advanced NSCLC. Additionally, we performed subgroup analysis according to specific TAs and found that the use of anti-EGFR agents in elderly patients with advanced NSCLC significantly improved PFS and OS, while anti-VEGF agents marginally improved PFS, but not for OS in these patients.
Further studies are still needed to identify patients who will most likely benefit from the appropriate TAs in elderly patients with advanced NSCLC.

Several limitations exist in this analysis. First, this metaanalysis considers only published literature, and lack of individual patient data prevents us from adjusting the treatment effect according to disease and patient variables. Second, elderly patients treated with different TAs were included for analysis, which would increase the clinical heterogeneity. Furthermore, our study could not answer which TA would be the best choice. Finally, publication bias is an important issue because trials with positive results are more likely to be published than trials with null results. Our research detects

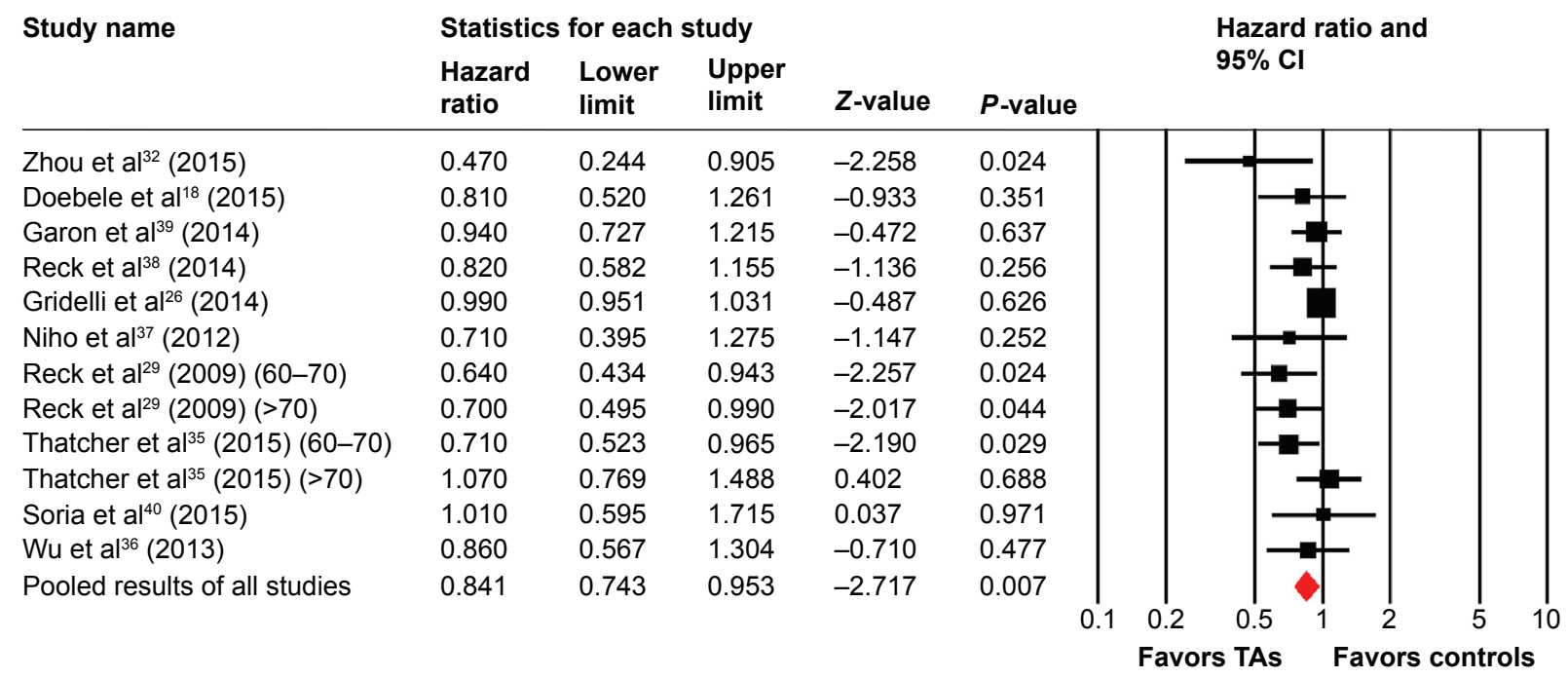

Figure 3 Random-effects model of hazard ratio $(95 \% \mathrm{Cl})$ of PFS associated with chemotherapy with or without TAs. Abbreviations: $\mathrm{Cl}$, confidence interval; PFS, progression-free survival; TA, targeted agent. 
no publication bias using Begg's and Egger's tests for OS but not for PFS.

\section{Conclusion}

This is the first meta-analysis specifically assessing the efficacy of adding TAs to chemotherapy in elderly patients with advanced NSCLC. The results of our study suggest that the addition of TAs to first-line chemotherapy in elderly patients with NSCLC offers an improved PFS and OS, when compared to chemotherapy alone. With present available data from randomized clinical trials, we could not clearly set the role of TAs in the second-line treatment for elderly patients with advanced NSCLC. Further studies are recommended to assess the efficacy of adding TAs to second-line chemotherapy for advanced NSCLC in this setting.

\section{Acknowledgment}

This work was funded by 2011 key project of Nanjing Military Region Innovation of Medical Science and Technology (serial number 11Z021).

\section{Disclosure}

The authors report no conflicts of interest in this work.

\section{References}

1. Siegel R, Naishadham D, Jemal A. Cancer statistics, 2013. CA Cancer J Clin. 2013;63(1):11-30.

2. Smith BD, Smith GL, Hurria A, Hortobagyi GN, Buchholz TA. Future of cancer incidence in the United States: burdens upon an aging, changing nation. J Clin Oncol. 2009;27(17):2758-2765.

3. Gajra A, Jatoi A. Non-small-cell lung cancer in elderly patients: a discussion of treatment options. J Clin Oncol. 2014;32(24):2562-2569.

4. Wingo PA, Cardinez CJ, Landis SH, et al. Long-term trends in cancer mortality in the United States, 1930-1998. Cancer. 2003;97(12 suppl): 3133-3275.

5. Yancik R, Ganz PA, Varricchio CG, Conley B. Perspectives on comorbidity and cancer in older patients: approaches to expand the knowledge base. J Clin Oncol. 2001;19(4):1147-1151.

6. Wang S, Wong ML, Hamilton N, Davoren JB, Jahan TM, Walter LC. Impact of age and comorbidity on non-small-cell lung cancer treatment in older veterans. J Clin Oncol. 2012;30(13):1447-1455.

7. Hutchins LF, Unger JM, Crowley JJ, Coltman CA Jr, Albain KS. Underrepresentation of patients 65 years of age or older in cancer-treatment trials. N Engl J Med. 1999;341(27):2061-2067.

8. Maione P, Rossi A, Sacco PC, et al. Treating advanced non-small cell lung cancer in the elderly. Ther Adv Med Oncol. 2010;2(4):251-260.

9. Blanco R, Maestu I, de la Torre MG, Cassinello A, Nunez I. A review of the management of elderly patients with non-small-cell lung cancer. Ann Oncol. 2015;26(3):451-463.

10. Langer CJ, Manola J, Bernardo P, et al. Cisplatin-based therapy for elderly patients with advanced non-small-cell lung cancer: implications of Eastern Cooperative Oncology Group 5592, a randomized trial. J Natl Cancer Inst. 2002;94(3):173-181.

11. Quoix E, Zalcman G, Oster JP, et al. Carboplatin and weekly paclitaxel doublet chemotherapy compared with monotherapy in elderly patients with advanced non-small-cell lung cancer: IFCT-0501 randomised, phase 3 trial. Lancet. 2011;378(9796):1079-1088.
12. Qi WX, Tang LN, He AN, Shen Z, Lin F, Yao Y. Doublet versus single cytotoxic agent as first-line treatment for elderly patients with advanced non-small-cell lung cancer: a systematic review and meta-analysis. Lung. 2012;190(5):477-485.

13. Des Guetz G, Uzzan B, Nicolas P, Valeyre D, Sebbane G, Morere JF. Comparison of the efficacy and safety of single-agent and doublet chemotherapy in advanced non-small cell lung cancer in the elderly: a meta-analysis. Crit Rev Oncol Hematol. 2012;84(3):340-349.

14. Qi WX, Fu S, Zhang Q, Guo XM. Anti-epidermal-growth-factorreceptor agents and complete responses in the treatment of advanced non-small-cell lung cancer: a meta-analysis of 17 phase III randomized controlled trials. Curr Med Res Opin. 2015;31(1):25-33.

15. Owonikoko TK, Ramalingam S. The role of targeted agents in the treatment of elderly patients with non-small cell lung cancer (NSCLC). Curr Treat Options Oncol. 2008;9(4-6):313-325.

16. Qi WX, Shen Z, Lin F, et al. Comparison of the efficacy and safety of EFGR tyrosine kinase inhibitor monotherapy with standard second-line chemotherapy in previously treated advanced non-small-cell lung cancer: a systematic review and meta-analysis. Asian Pac J Cancer Prev. 2012;13(10):5177-5182.

17. Sandler A, Gray R, Perry MC, et al. Paclitaxel-carboplatin alone or with bevacizumab for non-small-cell lung cancer. N Engl J Med. 2006; 355(24):2542-2550.

18. Doebele RC, Spigel D, Tehfe M, et al. Phase 2, randomized, openlabel study of ramucirumab in combination with first-line pemetrexed and platinum chemotherapy in patients with nonsquamous, advanced/metastatic non-small cell lung cancer. Cancer. 2015;121(6): $883-892$.

19. Gatzemeier U, Pluzanska A, Szczesna A, et al. Phase III study of erlotinib in combination with cisplatin and gemcitabine in advanced non-small-cell lung cancer: the Tarceva Lung Cancer Investigation Trial. J Clin Oncol. 2007;25(12):1545-1552.

20. Giaccone G, Herbst RS, Manegold C, et al. Gefitinib in combination with gemcitabine and cisplatin in advanced non-small-cell lung cancer: a phase III trial - INTACT 1. J Clin Oncol. 2004;22(5):777-784.

21. Herbst RS, Giaccone G, Schiller JH, et al. Gefitinib in combination with paclitaxel and carboplatin in advanced non-small-cell lung cancer: a phase III trial - INTACT 2. J Clin Oncol. 2004;22(5):785-794.

22. Moher D, Liberati A, Tetzlaff J, Altman DG; PRISMA Group. Preferred reporting items for systematic reviews and meta-analyses: the PRISMA statement. PLoS Med. 2009;6(7):e1000097.

23. Moher D, Pham B, Jones A, et al. Does quality of reports of randomised trials affect estimates of intervention efficacy reported in meta-analyses? Lancet. 1998;352(9128):609-613.

24. Zintzaras E, Ioannidis JP. Heterogeneity testing in meta-analysis of genome searches. Genet Epidemiol. 2005;28(2):123-137.

25. Vandenbroucke JP. Bias in meta-analysis detected by a simple, graphical test. Experts' views are still needed. BMJ. 1998;316(7129):469-470; author reply 470-471.

26. Gridelli C, Novello S, Zilembo N, et al. Phase II randomized study of vandetanib plus gemcitabine or gemcitabine plus placebo as first-line treatment of advanced non-small-cell lung cancer in elderly patients. J Thorac Oncol. 2014;9(5):733-737.

27. Hoang T, Dahlberg SE, Schiller JH, et al. Randomized phase III study of thoracic radiation in combination with paclitaxel and carboplatin with or without thalidomide in patients with stage III non-small-cell lung cancer: the ECOG 3598 study. J Clin Oncol. 2012;30(6):616-622.

28. Lynch TJ, Patel T, Dreisbach L, et al. Cetuximab and first-line taxane/ carboplatin chemotherapy in advanced non-small-cell lung cancer: results of the randomized multicenter phase III trial BMS099. J Clin Oncol. 2010;28(6):911-917.

29. Reck M, von Pawel J, Zatloukal P, et al. Phase III trial of cisplatin plus gemcitabine with either placebo or bevacizumab as first-line therapy for nonsquamous non-small-cell lung cancer: AVAil. J Clin Oncol. 2009; 27(8):1227-1234.

30. Scagliotti G, Novello S, von Pawel J, et al. Phase III study of carboplatin and paclitaxel alone or with sorafenib in advanced non-small-cell lung cancer. J Clin Oncol. 2010;28(11):1835-1842. 
31. Scagliotti GV, Vynnychenko I, Park K, et al. International, randomized, placebo-controlled, double-blind phase III study of motesanib plus carboplatin/paclitaxel in patients with advanced nonsquamous non-small-cell lung cancer: MONET1. J Clin Oncol. 2012;30(23):2829-2836.

32. Zhou C, Wu YL, Chen G, et al. BEYOND: a randomized, doubleblind, placebo-controlled, multicenter, phase III study of first-line carboplatin/paclitaxel plus bevacizumab or placebo in Chinese patients with advanced or recurrent nonsquamous non-small-cell lung cancer J Clin Oncol. 2015;33(19):2197-2204.

33. Pirker R, Pereira JR, Szczesna A, et al. Cetuximab plus chemotherapy in patients with advanced non-small-cell lung cancer (FLEX): an openlabel randomised phase III trial. Lancet. 2009;373(9674):1525-1531.

34. Paz-Ares L, Mezger J, Ciuleanu TE, et al. Necitumumab plus pemetrexed and cisplatin as first-line therapy in patients with stage IV non-squamous non-small-cell lung cancer (INSPIRE): an open-label, randomised, controlled phase 3 study. Lancet Oncol. 2015;16(3):328-337.

35. Thatcher N, Hirsch FR, Luft AV, et al. Necitumumab plus gemcitabine and cisplatin versus gemcitabine and cisplatin alone as first-line therapy in patients with stage IV squamous non-small-cell lung cancer (SQUIRE): an open-label, randomised, controlled phase 3 trial. Lancet Oncol. 2015;16(7):763-774.

36. Wu YL, Lee JS, Thongprasert S, et al. Intercalated combination of chemotherapy and erlotinib for patients with advanced stage non-small-cell lung cancer (FASTACT-2): a randomised, double-blind trial. Lancet Oncol. 2013;14(8):777-786.
37. Niho S, Kunitoh H, Nokihara H, et al. Randomized phase II study of first-line carboplatin-paclitaxel with or without bevacizumab in Japanese patients with advanced non-squamous non-small-cell lung cancer. Lung Cancer. 2012;76(3):362-367.

38. Reck M, Kaiser R, Mellemgaard A, et al; LUME-Lung 1 Study Group. Docetaxel plus nintedanib versus docetaxel plus placebo in patients with previously treated non-small-cell lung cancer (LUME-Lung 1): a phase 3, double-blind, randomised controlled trial. Lancet Oncol. 2014; 15(2):143-155.

39. Garon EB, Ciuleanu TE, Arrieta O, et al. Ramucirumab plus docetaxel versus placebo plus docetaxel for second-line treatment of stage IV non-small-cell lung cancer after disease progression on platinum-based therapy (REVEL): a multicentre, double-blind, randomised phase 3 trial. Lancet. 2014;384(9944):665-673.

40. Soria JC, Wu YL, Nakagawa K, et al. Gefitinib plus chemotherapy versus placebo plus chemotherapy in EGFR-mutation-positive non-small-cell lung cancer after progression on first-line gefitinib (IMPRESS) a phase 3 randomised trial. Lancet Oncol. 2015;16(8):990-998.

41. Sterne JA, Gavaghan D, Egger M. Publication and related bias in metaanalysis: power of statistical tests and prevalence in the literature. J Clin Epidemiol. 2000;53(11):1119-1129.

42. Lauro S, Onesti CE, Righini R, Marchetti P. The use of bevacizumab in non-small cell lung cancer: an update. Anticancer Res. 2014;34(4): $1537-1545$.

43. Crino L, Metro G. Therapeutic options targeting angiogenesis in nonsmall cell lung cancer. Eur Respir Rev. 2014;23(131):79-91.
OncoTargets and Therapy

\section{Publish your work in this journal}

OncoTargets and Therapy is an international, peer-reviewed, open access journal focusing on the pathological basis of all cancers, potential targets for therapy and treatment protocols employed to improve the management of cancer patients. The journal also focuses on the impact of management programs and new therapeutic agents and protocols on

\section{Dovepress}

patient perspectives such as quality of life, adherence and satisfaction. The manuscript management system is completely online and includes a very quick and fair peer-review system, which is all easy to use. Visit http://www.dovepress.com/testimonials.php to read real quotes from published authors. 